\title{
Pengaruh perubahan telajakan dan apa dampak terhadap ruang terbuka hijau di Kelurahan Penatih, Denpasar Timur
}

\author{
I Gusti Ngurah Aditya Aryadiva ${ }^{1}$, Cokorda Gede Alit Semarajaya ${ }^{1 *}$, I Nyoman Gede Astawa²
}

1. Prodi Arsitektur Pertamanan, Fakultas Pertanian, Universitas Udayana, Denpasar, Indonesia, 80232

2. Prodi Agroekoteknologi, Fakultas Pertanian, Universitas Udayana, Denpasar, Indonesia, 80232

*Email: coksemarajaya@unud.ac.id

\begin{abstract}
The effect of changes telajakan and what impact on green open space in Kelurahan Penatih, Denpasar Timur Telajakan is one of Bali's ancestral heritage which is usually used as a garden with various types of vegetation in it. However, currently telajakan has changed a lot. The purpose of this research is to know what factors caused the change of telajakan and what changes happened to green open space in the research location. Data collection methods used were observation, interview and literature study. The tools used in supporting research were office stationery, hand phone, measuring instrument, digital camera, interview list, and computer peripheral, Microsoft Word, Auto CAD. Based on the results of this study, it can be concluded that the form of the change of telajakan into a place of selling due to economic factors. The width of the telajakan changed $936 \mathrm{~m}^{2}$ with a total area of $1028.5 \mathrm{~m}^{2}$ overall. The change of telajakan in Kelurahan Penetih was $91.1 \%$. The magnitude of changes that occurs can result in reducing green open space and affecting the micro climate in Penatih.
\end{abstract}

Keywords: green space, vegetation, front yard, land change

\section{Pendahuluan}

Pembangunan di wilayah perkotaan terus meningkat seiring dengan bertambahnya jumlah penduduk dan kebutuhan masyarakat akan sarana dan prasarana kota. Peningkatan jumlah penduduk menyebabkan semakin tingginya perubahan penggunaan lahan yang mengakibatkan berkurangnya jumlah tutupan lahan oleh vegetasi khususnya di daerah perkotaan, keadaan ini menyebabkan menurunnya kualitas lingkungan di daerah perkotaan (Dardak, 2006). Jumlah penduduk di kota Denpasar pada tahun 2015 telah mencapai 880,600 jiwa dengan laju pertumbuhan per tahun 1.97\% (BPS, 2016). Pesatnya laju pertumbuhan penduduk tersebut dapat menyebabkan semakin terdesaknya alokasi ruang untuk vegetasi yang mempunyai fungsi sangat penting untuk daerah perkotaan. PP RI No.63/2002 menyebutkan bahwa fungsi vegetasi di perumahan ditekankan sebagai penyerap $\mathrm{CO}^{2}$, penghasil oksigen, penyerap polutan, peredam kebisingan, penahan angin dan penambah nilai keindahan. Vegetasi yang terdapat pada perumahan tradisional di Bali salah satunya terdapat pada bagian depan rumah yaitu telajakan.

Telajakan adalah ruang yang terletak pada bagian depan rumah tepatnya pada sisi kiri dan kanan pintu masuk rumah yang ditanami berbagai jenis tanaman / vegetasi, dengan dimensi minimal satu (1) meter dan maksimal yaitu \pm dua (2) meter. Telajakan memiliki fungsi secara ekologis sebagai penghasil $\mathrm{O}^{2}$ dengan ada tumbuh-tumbuhan yang ditanam, penghijauan lingkungan, pemberi nilai keindahan secara estetika juga meningkatkan kenyamanan lingkungan, secara arsitektural dapat memperlebar jarak pandang, sebagai keamanan bangunan, dan secara sosial budaya telajakan dapat menjadi sarana berinteraksi antar manusia dan sebagai tempat menancapkan penjor, serta menjadi identitas suatu lingkungan, sehingga telajakan dikategorikan sebagai salah satu elemen ruang terbuka hijau tradisional di Bali (Dwijendra, 2008). Telajakan secara tidak langsung dapat menggambarkan karakter pemilik rumah. Pemilik rumah yang sadar mengetahui pentingnya telajakan, cenderung memiliki penataan telajakan yang lebih rapi sesuai dengan ketentuan yang ada dalam aturan membuat telajakan (Wijaya, 2012).

Ketersediaan Ruang Terbuka Hijau (RTH) khususnya pada wilayah perkotaan sangat penting mengingat besarnya manfaat yang diperoleh dari keberadaan RTH tersebut. Perkembangan kota menyebabnya terjadinya perubahan kondisi ekologis lingkungan perkotaan yang mengakibatkan penurunan 
kualitas lingkungan. UU No. 26 Tahun 2007 tentang penataan ruang, mengharuskan proporsi ruang terbuka hijau sebanyak 30\% dengan rincian sebesar 20\% ruang terbuka hijau publik, dan 10\% ruang terbuka hijau privat dari luas wilayahnya. Berdasarkan pada Peraturan Walikotamadya Kepala Daerah Tingkat II Denpasar, No. 41 Tahun 1995 tentang Garis Sempadan Bangunan ditetapkan Kelurahan Penatih memiliki lebar badan jalan 11 meter, rencana garis sempadan bangunan minimum sembilan (9) meter, dan rencana telajakan dari tepi got jalan minimum satu (1) meter. Saat ini telajakan depan rumah yang terdapat di Kelurahan Penatih cenderung telah dirubah fungsinya mernjadi bangunan permanen, secara tidak langsung hal tersebut akan mempengaruhi jumlah ruang terbuka hijau di Kelurahan Penatih. Terkait dengan hal tersebut, diperlukan penelitian untuk mengetahui tingkat perubahan dan faktor-faktor yang menyebabkan terjadinya perubahan telajakan serta dampak apa yang dapat terjadi pada ruang terbuka hijau di Kelurahan Penatih.

\section{Metode}

Penelitian dilaksanakan di Kelurahan Penatih, Kecamatan Denpasar Timur, Kota Denpasar. Kegiatan penelitian dilaksanakan selama 11 bulan dari tahap persiapan hingga laporan yaitu dari Bulan Februari 2017 sampai dengan Desember 2017. Peta lokasi penelitian disajikan pada Gambar 1. Alat yang digunakan dalam penelitian di lapangan antara lain adalah alat tulis kantor, alat ukur, kamera digital, hand phone, daftar wawancara, dan perangkat komputer, Microsoft Word, Auto CAD, untuk mengolah data. Metode yang digunakan dalam penelitian adalah metode survei, dengan teknik pengumpulan data observasi, penyebaran kuisioner, wawancara, dan studi pustaka.

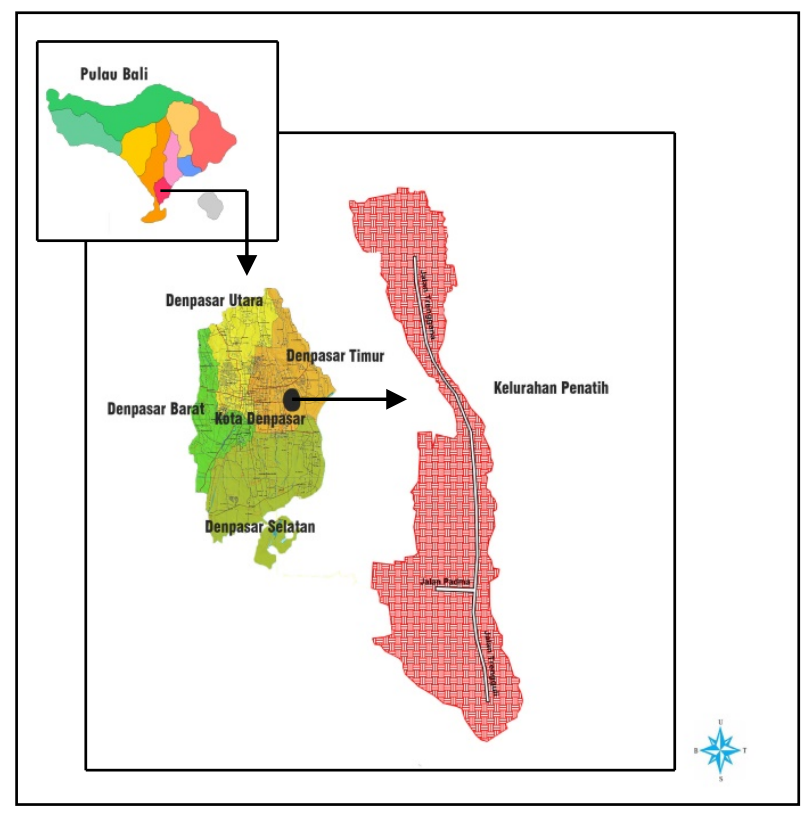

Gambar 1. Lokasi penelitian

\section{Hasil dan Pembahasan}

\subsection{Lokasi Studi}

Kelurahan Penatih merupakan salah satu kelurahan yang berada di wilayah Kecamatan Denpasar Timur, Kota Denpasar. Kelurahan Penatih memiliki luas wilayah $281 \mathrm{Ha}$ yang terdiri dari 10 Lingkungan dan empat (4) Desa Adat Pekraman. Jumlah Penduduk di Kelurahan Penatih yaitu 9500 orang, dengan jumlah laki-laki sebanyak 4763 orang dan perempuan 4737 orang dengan jumlah kepala keluarga 2395 KK yang tersebar di sepuluh lingkungan. yaitu lingkungan Anggabaya, lingkungan Pelagan, lingkungan Paang Kaja, lingkungan Paang Tengah, lingkungan Paang Kelod, lingkungan Semaga, lingkungan Saba, lingkungan Tembau Kaja, lingkungan Tembau Tengah, lingkungan Tembau Kelod. Lokasi dengan batas wilayah Kelurahan Penatih dapat dilihat pada Gambar 2. 


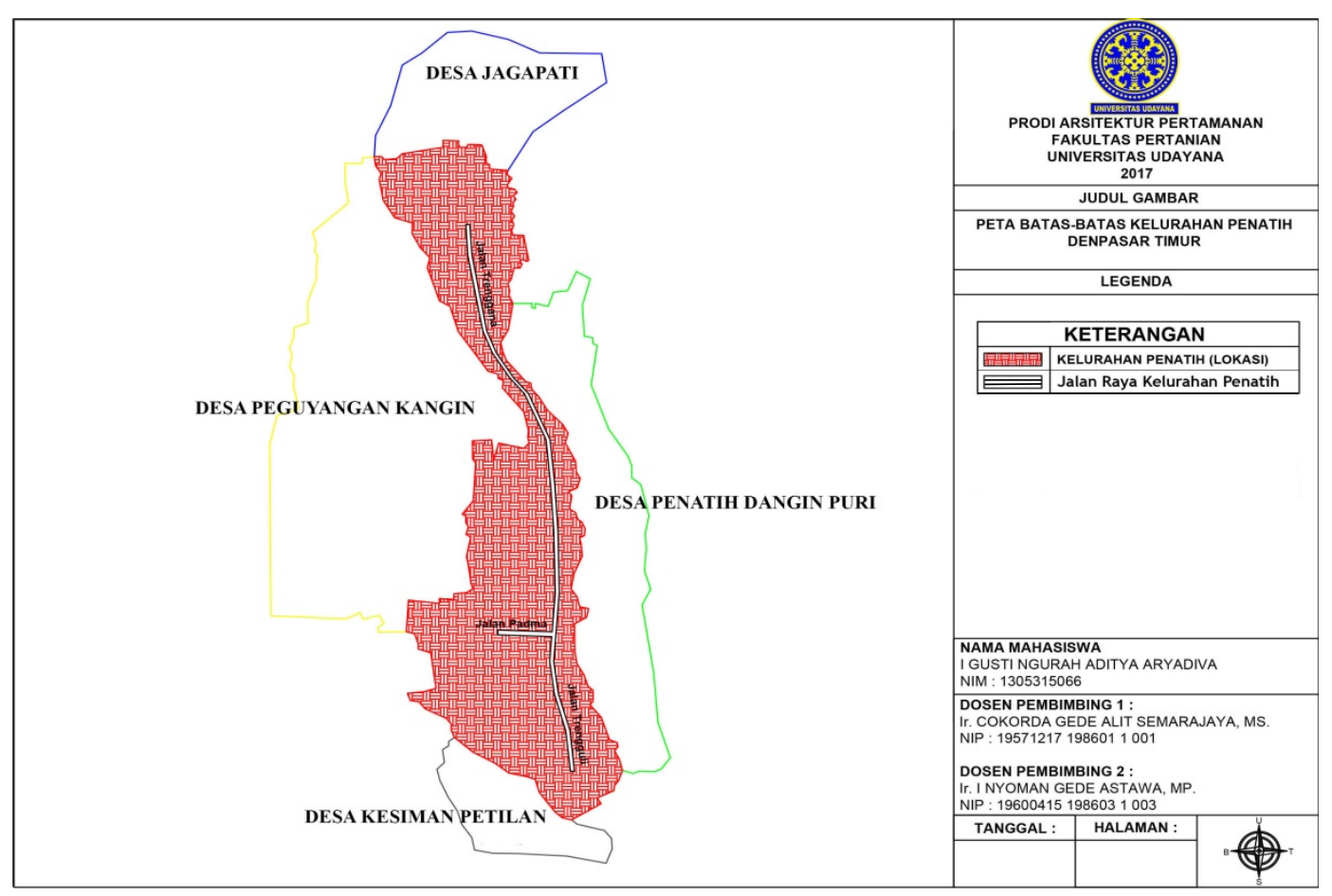

Gambar 2. Batas Wilayah Kelurahan Penatih

\subsection{Jalan Raya di Kelurahan Penatih}

Menurut Sukirman (1994) jalan raya adalah jalur - jalur tanah di atas permukaan bumi yang dibuat oleh manusia dengan bentuk, ukuran - ukuran dan jenis konstruksinya sehingga dapat digunakan untuk menyalurkan lalu lintas orang, hewan dan kendaraan yang mengangkut barang dari suatu tempat ke tempat lainnya dengan cepat dan mudah. Jalan Padma, jalan Terenggana, jalan Terengguli merupakan jalan raya yang terdapat di Kelurahan Penatih Denpasar Timur, setiap jalan memiliki panjang yang berbeda, yaitu panjang Jalan Padma hingga perbatasan Desa Peguyangan Kangin yaitu 706 meter, sedangkan panjang Jalan Terenggana hingga perbatasan desa Jagapati yaitu 2,995 meter dan panjang Jalan Terengguli hingga perbatasan desa Kesiman Petilan yaitu 1,719 meter (Gambar 2).

\subsection{Perubahan Telajakan dan Faktor Penyebab}

Telajakan merupakan salah satu ruang terbuka hijau tradisional di Bali, Menurut Dwijendra (2008) telajakan rumah terletak dibagian sisi kiri dan kanan pintu masuk rumah atau angkul-angkul, dari segi dimensi telajakan minimal selebar sangkar ayam atau kurang lebih satu meter, dan maksimal selebar tangan merentang dari pemilik rumah atau juga dapat memakai lebar dari asanan padi yaitu kurang lebih 2,20 meter dapat dilihat pada Gambar 3 \& Gambar 4.

Tanaman pada telajakan dapat dikatakan sebagai sarana pengendali iklim mikro dikarenakan tanaman yang terdapat pada telajakan tersebut juga dapat berfungsi sebagai peneduh pada siang hari, sinar matahari tidak langsung mengenai permukaan tanah, sinar matahari akan mengenai tanaman yang terdapat pada telajakan dan membuat lingkungan disekitar telajakan tersebut sejuk (Gambar 4). Tanaman menyerap sinar matahari untuk keperluan fotosintesis, hal tersebut sesuai dengan penelitian Hakim (2012) yang menyatakan bahwa tanaman dapat menciptakan iklim mikro, yaitu adanya penurunan suhu sekitar, kelembaban yang cukup dan kadar $\mathrm{O}^{2}$ yang bertambah. 


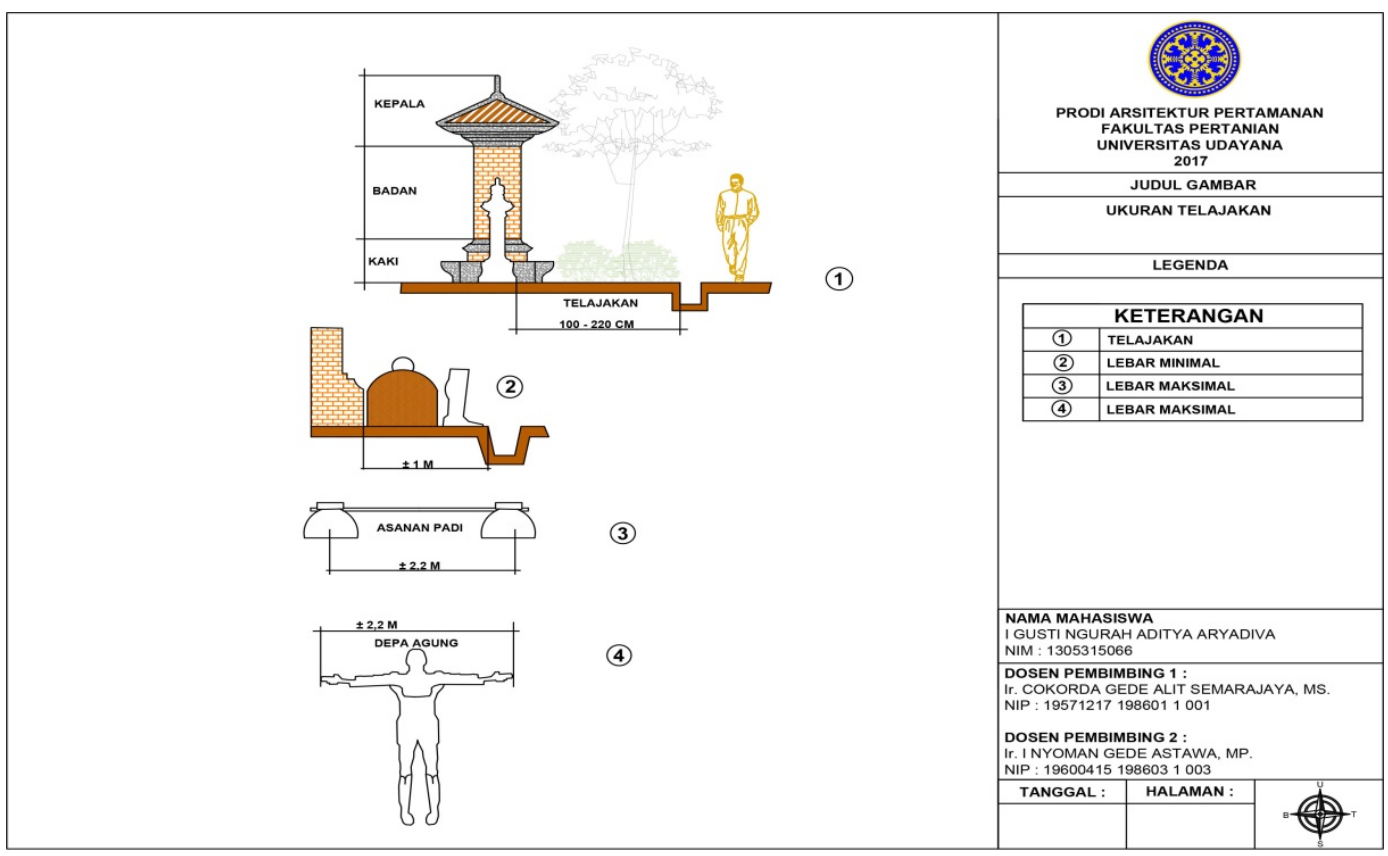

Gambar 3. Ukuran Telajakan Depan Rumah (Dwijendra, 2008)

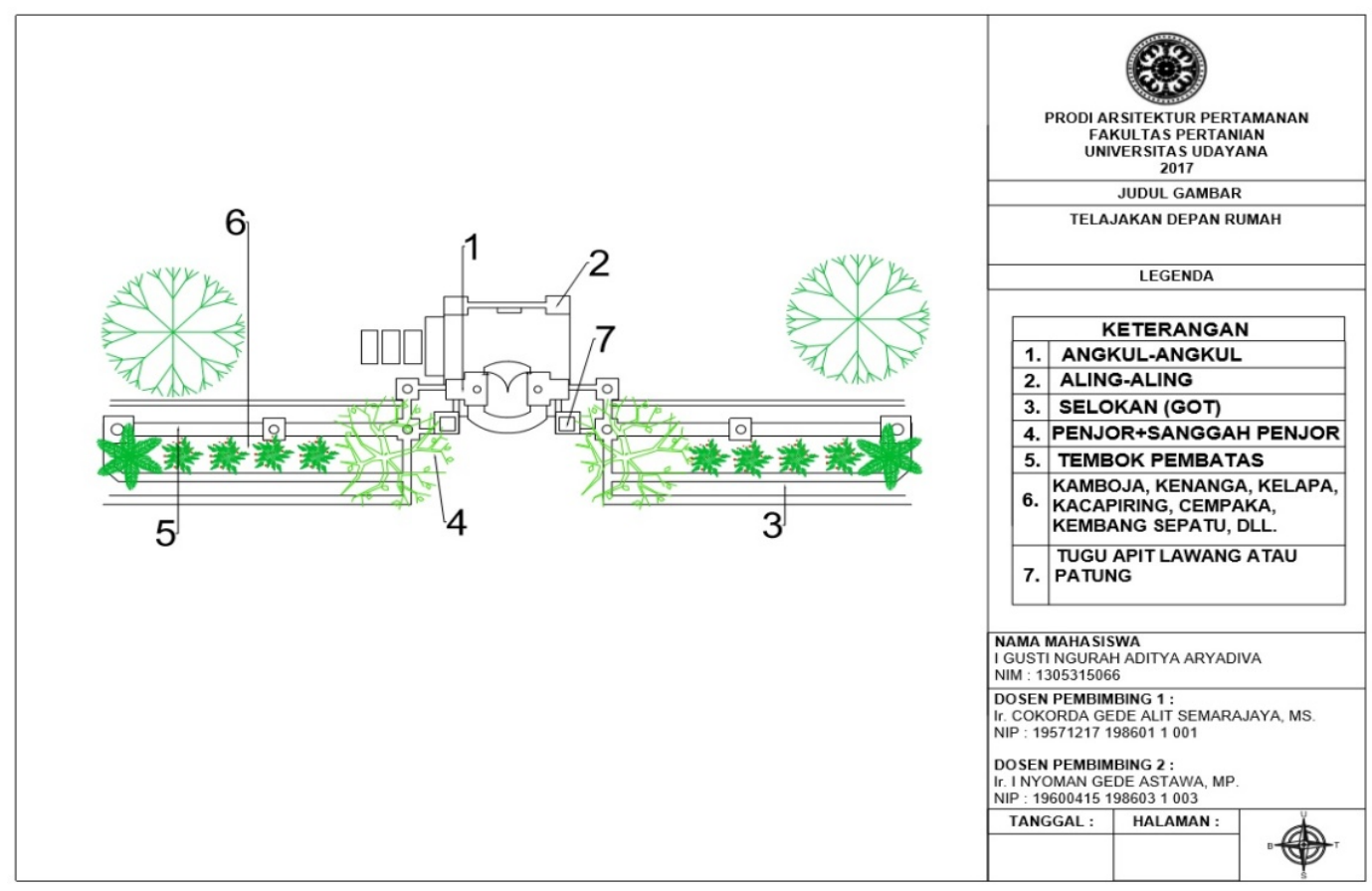

Gambar 4. Telajakan Depan Rumah

Observasi dan wawancara jumlah perubahan fungsi telajakan pada rumah warga yang dilakukan di lokasi penelitian yaitu jalan Padma, Terenggana dan Terengguli mengambil 30 responden menyebar pada tiga (3) jalan tersebut dapat dilihat pada Gambar 5. Luasan perubahan telajakan pada masing-masing jalan raya bervariasi. Rumah warga di jalan Padma yang melakukan perubahan fungsi telajakan sebanyak 8 unit dengan luas perubahan $282 \mathrm{~m}^{2}$. Terdapat beberapa telajakan yang masih ada seluas $3,9 \mathrm{~m}^{2}$ dari luas keseluruhan $285,9 \mathrm{~m}^{2}$ yang dapat dilihat pada Gambar 6 . Pada jalan Terenggana terdapat 12 unit rumah warga yang melakukan perubahan fungsi telajakan dengan luas $403 \mathrm{~m}^{2}$. Luas telajakan yang masih ada $47 \mathrm{~m}^{2}$ dengan luas keseluruhan $540 \mathrm{~m}^{2}$ (Gambar 7). Jalan Terengguli terdapat 10 unit rumah warga yang melakukan 
perubahan pada telajakan dengan luas $251 \mathrm{~m}^{2}$. Jumlah telajakan yang masih ada $41,6 \mathrm{~m}^{2}$ dari luas keseluruhan 292,6 $\mathrm{m}^{2}$ (Gambar 8). Perubahan telajakan pada rumah warga di jalan raya Kelurahan Penatih yaitu $936 \mathrm{~m}^{2}$. Luas telajakan yang tersisa adalah 92,5 $\mathrm{m}^{2}$ dari luas keseluruhan 1028,5 $\mathrm{m}^{2}$ (Tabel 1).

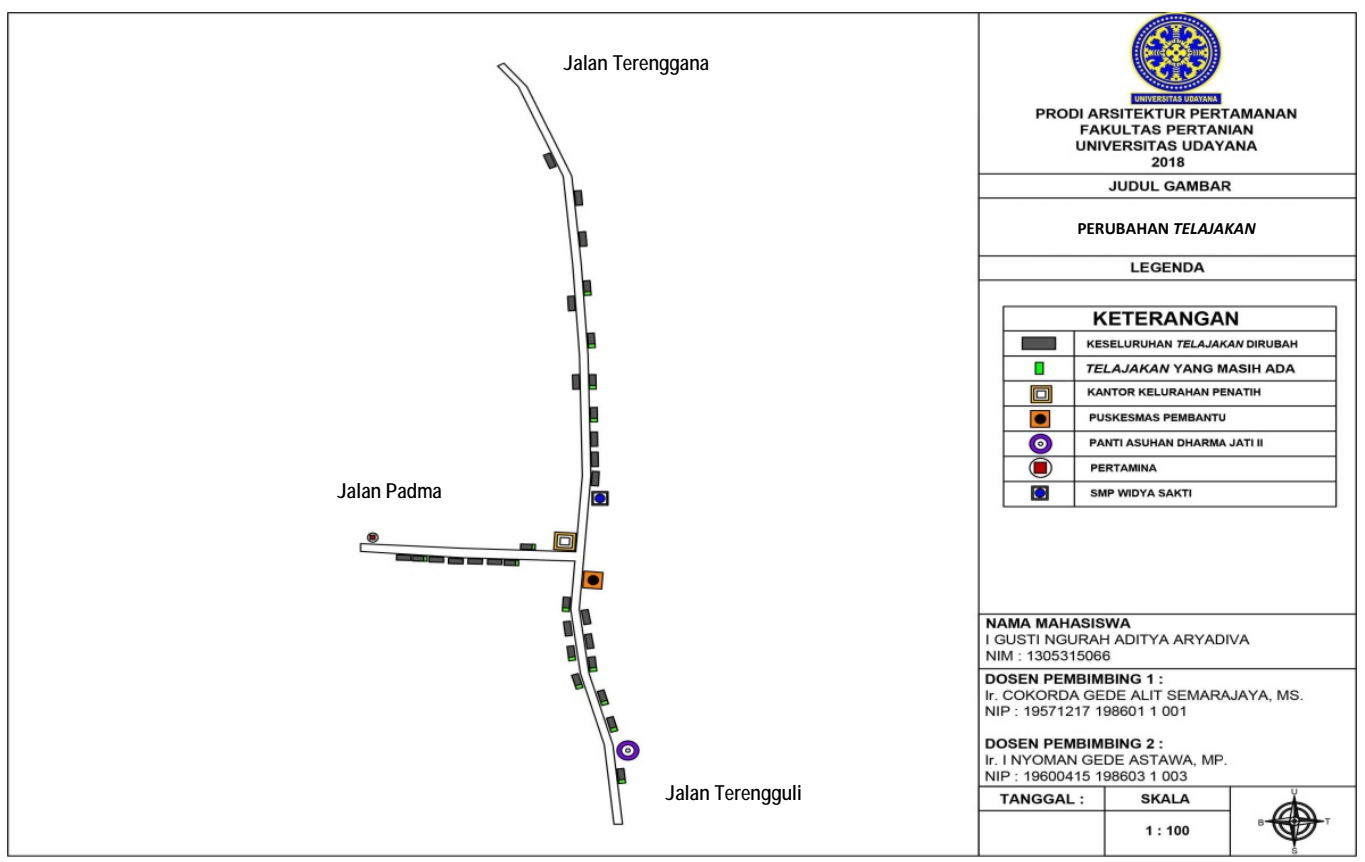

Gambar 5. Responden Keseluruhan di Kelurahan Penatih

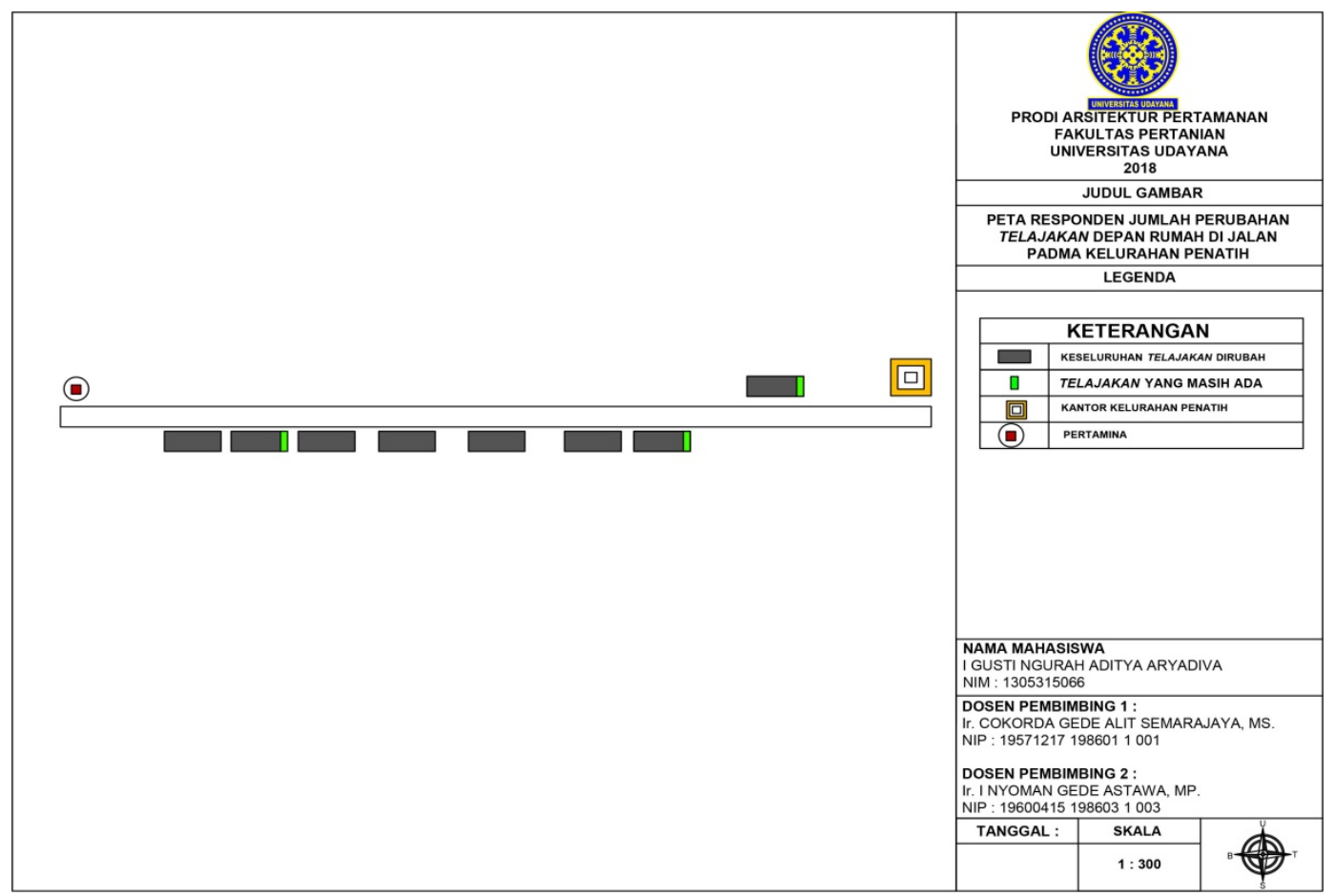

Gambar 6. Responden Perubahan Fungsi Telajakan Depan Rumah di Jalan Padma 


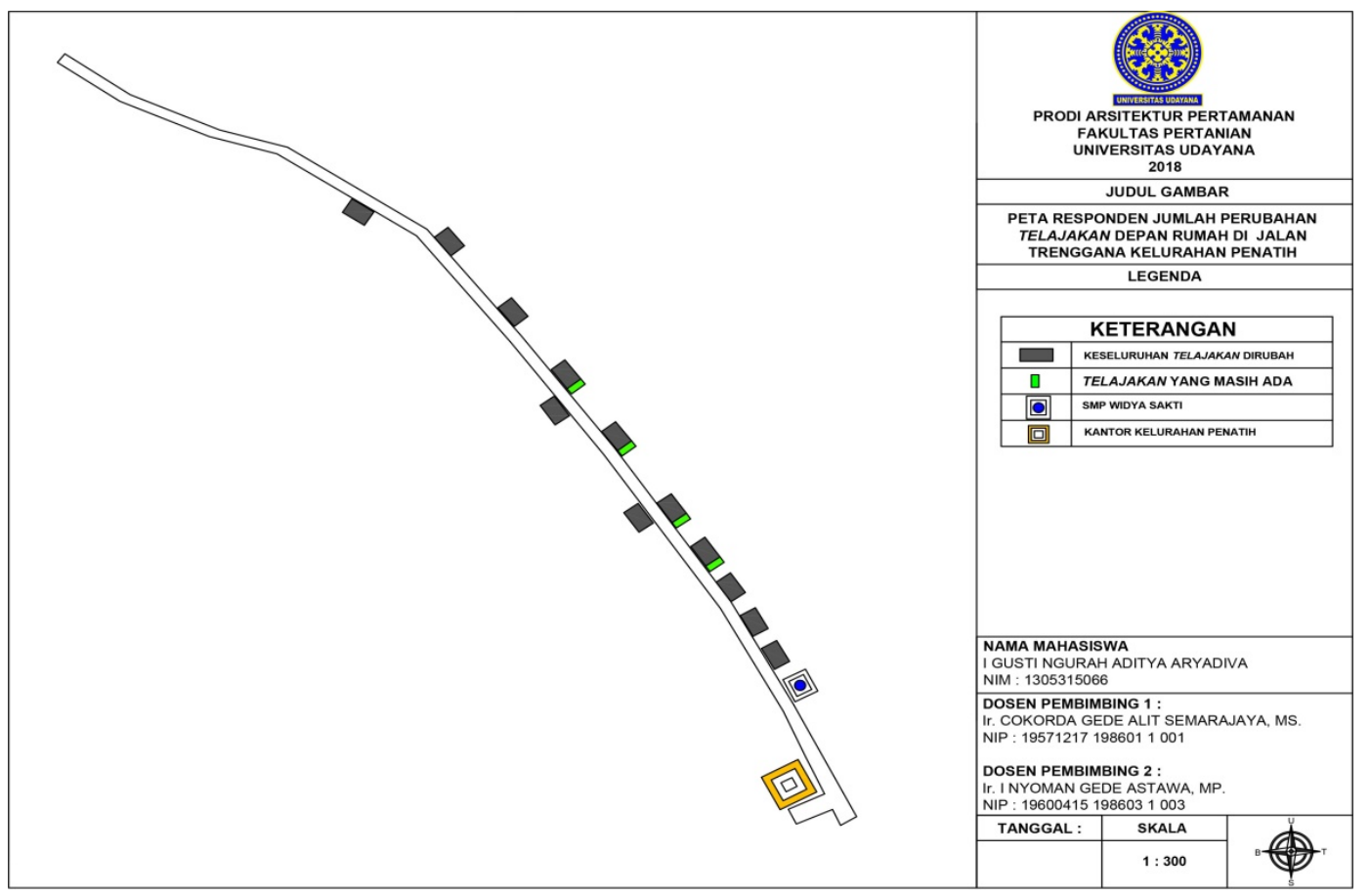

Gambar 7. Responden Perubahan Fungsi Telajakan Depan Rumah di Jalan Terenggana

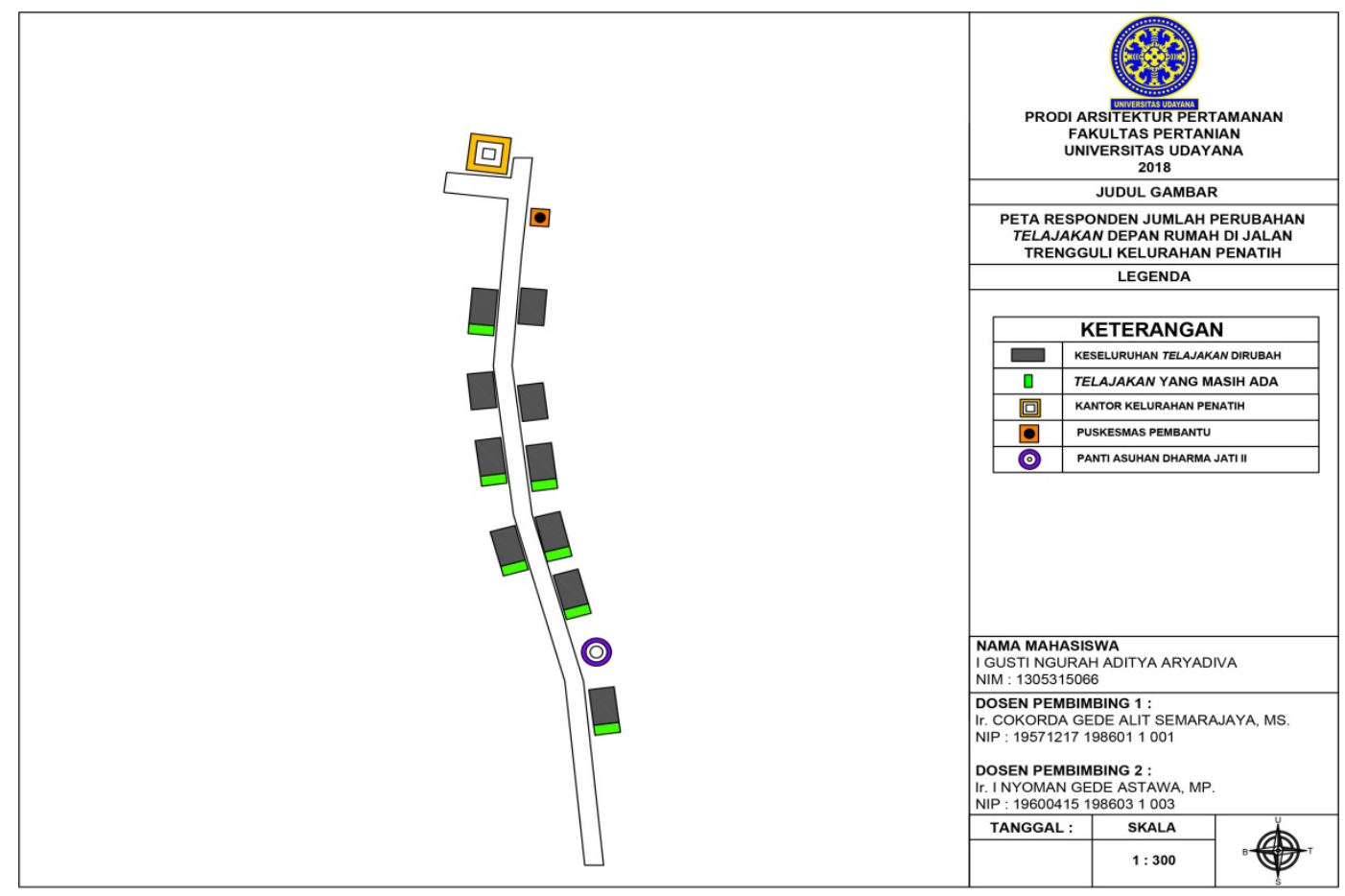

Gambar 8. Responden Perubahan Fungsi Telajakan Depan Rumah di Jalan Terengguli 
Tabel 1. Hasil Pengukuran Perubahan Telajakan

\begin{tabular}{clccc}
\hline No & Lokasi & Luas keseluruhan $\left(\mathrm{m}^{2}\right)$ & \multicolumn{2}{c}{ Luas perubahan } \\
\cline { 3 - 5 } & & $\left(\mathrm{m}^{2}\right)$ & $(\%)$ \\
\hline 1 & Jalan Padma & 285,9 & 282 & 98,7 \\
2 & Jalan Trengguli & 292,6 & 251 & 89,6 \\
3 & Jalan Trenggana & 450 & 403 & 85,7 \\
& Total & 1028,5 & 936 & \\
\hline
\end{tabular}

Berdasarkan hasil observasi yang dilakukan, perubahan telajakan yang terjadi seluruhnya menjadi tempat berjualan (Gambar 9). Dengan demikian faktor penyebab terjadinya perubahan telajakan adalah karena faktor ekonomi. Tidak adanya peraturan yang mengatur tentang perubahan telajakan pada rumah warga juga mengakibatkan tingginya tingkat perubahan telajakan yang terjadi dan berkurangnya ruang terbuka hijau yang ada. Luas ruang terbuka hijau di Kelurahan Penatih yaitu $185 \mathrm{Ha}$ (Profil Kelurahan Penatih Tahun, 2016). Banyaknya perubahan telajakan yang terjadi dengan luas $936 \mathrm{~m}^{2}$ dapat mengakibatkan berkurangnya ruang terbuka hijau sebesar $0.05 \%$ dan secara tidak langsung dapat berpengaruh pada iklim mikro di Kelurahan Penatih.

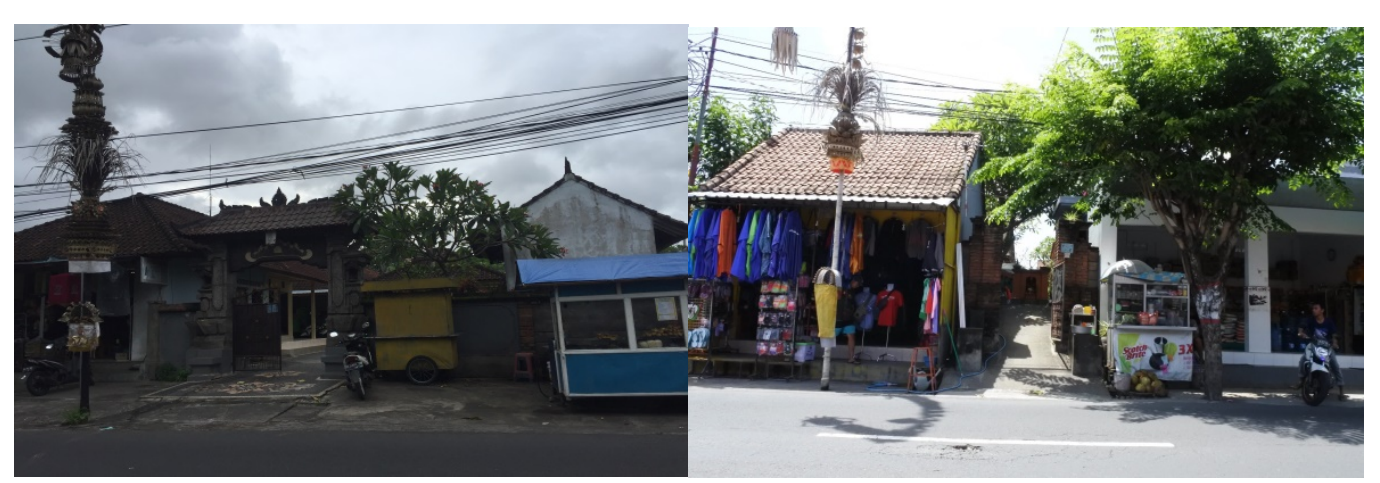

Gambar 9. Telajakan di Jalan Terenggana yang Sudah Berubah Menjadi Tempat Berjualan.

Perubahan telajakan menjadi tempat berjualan, secara tidak langsung mempengaruhi keberadaan vegetasi. Berkurangnya jumlah vegetasi akan menyebabkan meningkatnya suhu udara. Hal tersebut sesuai dengan penelitian Tauhid (2008), yang menyatakan bahwa suhu udara meningkat disebabkan karena pancaran radiasi matahari, energi matahari yang diterima berbagai benda di permukaan bumi kemudian memantulkan sebagian besar energi yang diterimanya kecuali vegetasi. Vegetasi sangat berpengaruh dalam pengatur suhu di lingkungan sekitar. Mustikaweni (2008) menyatakan bahwa peningkatan lahan terbangun yang berarti peningkatan penutupan lahan berupa perkerasan, aspal, conblock atau semen menjadi salah satu faktor pendorong peningkatan iklim mikro.

Perkembangan perubahan fungsi telajakan tempat berjualan di Kelurahan Penatih dari sampel yang diperoleh di lapangan melalui wawancara kepada warga yang melakukan perubahan pada telajakan mereka dapat dilihat pada Tabel 2. Perubahan telajakan di sepanjang jalan utama Kelurahan Penatih yaitu sebanyak sembilan (9) responden mengatakan merubah telajakan miliknya sebelum tahun 2000 dan sebanyak 21 responden mengatakan merubah telajakan miliknya setelah tahun 2000. Banyaknya telajakan yang berubah setelah tahun 2000 disebabkan semakin bertambahnya jumlah penduduk dan semakin ramainya lalulintas di jalan raya Kelurahan Penatih. Masyarakat ingin memanfaatkan lahan yang tersedia untuk kegiatan perekonomian mereka. 
Tabel 2. Perkembangan Perubahan telajakan

\begin{tabular}{lcc}
\hline No & Tahun & Jumlah \\
\hline 1 & $<2000$ & $30 \%$ \\
2 & $>2000$ & $70 \%$ \\
& Total & $100 \%$ \\
\hline
\end{tabular}

Mengingat cukup tingginya perubahan telajakan ini, perlu dibuat peraturan untuk mengontrol tingkat perubahan telajakan di tingkat Kelurahan Penatih Denpasar timur. Hal ini disebabkan karena aturan terkait dengan perubahan telajakan belum ada. Hasil wawancara dengan Bapak Wayan Astawa selaku Lurah, menyatakan belum ada larangan untuk merubah telajakan penduduk. Mengingat lahan telajakan merupakan milik pribadi masyarakat. Adanya peraturan perubahan telajakan diharapkan dapat mengendalikan perubahan telajakan yang terjadi. Jika harus terjadi alih fungsi telajakan, cukup salah satu sisi dari telajakan saja yang berubah. Usaha pelestarian telajakan dari alih fungsi ini sudah didukung oleh Peraturan Walikotamadya Kepala Daerah Tingkat II Denpasar Nomor 41 Tahun 1995. Aturan ini menetapkan Garis Sempadan Bangunan di Kelurahan Penatih yaitu lebar badan jalan 11 meter, rencana garis sempadan bangunan minimum sembilan (9) meter dan rencana telajakan dari tepi got jalan minimum satu (1) meter.

\section{Simpulan dan Saran}

\subsection{Simpulan}

Telajakan depan rumah di Kelurahan Penatih Denpasar Timur beralih fungsi menjadi tempat berjualan disebabkan oleh faktor ekonomi. Luas perubahan telajakan di Kelurahan Penatih $936 \mathrm{~m}^{2}$ dari total luasan keseluruhan $1028,5 \mathrm{~m}^{2}$. Perubahan telajakan yang terjadi sebesar $91,1 \%$ dan mengakibatkan berkurangnya ruang terbuka hijau sebesar $0.05 \%$ dan perubahan suhu mikro di Kelurahan Penatih Denpasar Timur.

\subsection{Saran}

Peraturan perlu dibuat untuk mengendalikan perubahan telajakan yang terjadi. Untuk telajakan yang sudah berubah usaha yang dapat dilakukan untuk meningkatkan kenyamanan pengguna tapak adalah dengan membuat taman vertical dengan cara memanfaatkan tembok dari bagunan dan taman atap bagi masyarakat yang memiliki bangunan berlantai dua, juga menyediakan tanaman dalam pot/planter box kemudian diletakkan berdampingan dengan bangunan / tempat berjualan. Tanaman yang dapat digunakan adalah jenis tanaman yang dapat membantu mengatasi polusi udara dan meningkatkan kualitas lingkungan di Kelurahan Penatih Denpasar timur.

\section{Daftar Pustaka}

BPS. 2016. Denpasar dalam Angka 2016. Badan Pusat Statistik. Denpasar.

Dardak, A.H. 2006." Peran Penataan Ruang dalam Mewujudkan Kota Berkelanjutan di Indonesia". Seminar Penataan Ruang Berbasis Aspek Ekologis untuk Mewujudkan Kota Berkelanjutan. Jakarta.

Dwijendra, N. K. A. 2008. Arsitektur Rumah Tradisional Bali. Denpasar Bali. 83-87.

Hakim, R. 2012." Komponen Perencanaan Aeritektur Lanskap".

Kelurahan Penatih 2016. Profil Potensi Kelurahan Penatih Kecamatan Denpasar Timur Kota Denpasar, 2016.

Mustikaweni, R 2008. Pengaruh Perubahan Pemanfaatan Ruang Kawasan Lingkar Luar Kebun Raya Bogor Terhadap Iklim Mikro. Skripsi. Bogor: Program Studi Arsitektur Lanskap Fakultas Pertanian Institut Pertanian Bogor.

Sukirman, S 1994, Dasar - Dasar Perencanaan Geometrik Jalan. Penerbit Nova, Bandung.

Tauhid.2008. Kajian jarak jangkau efek vegetasi pohon terhadap suhu udara pada siang hari di perkotaan.Tesis. Universitas Diponegoro. Semarang.

Wijaya, T. 2012. Telajakan Sebagai Kearifan Lokal di Bali. 